China Perspectives

51 | january-february 2004

Varia

\title{
Bilateral Aid To Improve Human Rights
}

Donors need to adopt a more coherent and thoughtful strategy

\section{Sophia Woodman}

\section{(2) OpenEdition}

\section{Journals}

Édition électronique

URL : http://journals.openedition.org/chinaperspectives/788

ISSN : 1996-4617

\section{Éditeur}

Centre d'étude français sur la Chine contemporaine

\section{Édition imprimée}

Date de publication : 1 février 2004

ISSN : 2070-3449

\section{Référence électronique}

Sophia Woodman, «Bilateral Aid To Improve Human Rights », China Perspectives [En ligne], 51 | january-february 2004, mis en ligne le 20 avril 2007, consulté le 28 octobre 2019. URL : http:// journals.openedition.org/chinaperspectives/788

Ce document a été généré automatiquement le 28 octobre 2019

(c) All rights reserved 


\section{Bilateral Aid To Improve Human Rights}

Donors need to adopt a more coherent and thoughtful strategy

\section{Sophia Woodman}

1 Aid to legal projects in China aimed, in the eyes of the donors, at improving human rights conditions on the ground there have become a centrepiece of the policy of many Western countries towards China's human rights situation since the late $1990 \mathrm{~s}^{1}$. These projects are part of a package of bilateral "dialogue and co-operation" that replaced the more critical multilateral approaches focused on the annual effort to pass resolutions at the annual sessions of the UN Commission on Human Rights that had been the principal vehicle for Western states' concerns about continuing human rights violations in China in the early to mid 1990 s $^{2}$.

2 The alternative approach taken up combined regular "dialogues" in which human rights were discussed, mostly between diplomats behind closed doors, but also sometimes including accompanying seminars bringing together "experts" from both sides, and Western-funded "co-operation" programmes in China to address human rights concerns through a variety of projects. The most common focus of these projects has been law and legal reform, as both China and its partners chose this as an acceptably neutral entry point for their co-operation.

3 This article examines the strategy behind programmes of bilateral aid directed to legal reform and law-related projects ${ }^{3}$ in China of nine countries: Australia, Canada, Denmark, France, Germany, the Netherlands, Norway, Sweden and the United Kingdom (UK); and one regional institution, the European Union (EU).

4 The choice of countries has been determined by two main criteria: programmes are part of a "human rights dialogue and co-operation" package that has been underway in most cases for five or more years ${ }^{4}$, and a substantial programme of aid to legal projects has been established during this period which is more or less explicitly linked to the human rights dialogues, and thus to achieving human rights objectives ${ }^{5}$. Information on these programmes has been collected from a variety of sources, including 
documentation provided by governments and implementing agencies ${ }^{6}$ and interviews with staff of the implementing agencies and with representatives of donors 7 .

Although it has made a substantial commitment to funding "rule of law" programmes in China, in part as a way to address human rights concerns, the United States is not included in this study as it has not really adopted the "dialogue and co-operation" approach, since a corollary of this is eschewing more critical action on China's human rights situation, particularly the sponsoring of censure resolutions at the UN Commission on Human Rights, and the US-China dialogue on human rights has been more off than on over the last few years. In addition, there has already been significant examination by scholars of US-funded legal programmes in China ${ }^{8}$, while, to my knowledge, almost nothing has been written in English on the programmes studied here.

Standards of assessment

6 Even when researchers have direct access to all relevant data, such as internal project documents, participants and intended beneficiaries, the impact of aid-funded projects that seek to change ideas and address entrenched patterns of institutional behaviour is notoriously hard to assess. Causation is often difficult to establish, and inputs may not be of a kind that can be expected to have an immediate effect. Given the lack of transparency of many donors in relation to the programmes under review here, the broad comparative scope of the study and the fact that many projects are likely to have a long-term rather than immediate impact, making such judgements on the China projects would be unwise, if not impossible. Thus the aim of this research project has not been to assess the effects of the aid programmes under review, but to examine the strategy that has informed them, reflected in their procedures and substantive content, in order to determine whether they are employing the most effective means and methods available, in the circumstances, to achieve the objective of improving human rights. This approach has been informed by study of the practice of such aid elsewhere.

7 Although human rights has been a factor in the aid policies of many countries since the 1970s, significant attempts to use aid as a mechanism for achieving improvements in human rights conditions were not seen until the 1980s and 1990s ${ }^{9}$. Despite this shift, political aid has been much less studied than development aid generally, while even fewer researchers have sought to examine aid programmes specifically aimed at achieving human rights objectives ${ }^{10}$. Since much assistance to legal projects has tended to be concentrated on working towards economic goals-whether through advice and support for the drafting of economic, financial and commercial laws, or through support for strengthening legal institutions-study of aid to legal programmes has also often neglected the human rights dimension.

8 However, a number of excellent studies published in the past few years do provide some standards that can be applied to the programmes under review in this paper ${ }^{11}$. In particular, a 2000 report by the International Council on Human Rights Policy examined foreign aid to civil and criminal law-related programmes in four countries, with a focus on collecting the views of recipients of aid ${ }^{12}$.The conclusions of this study are the most applicable to the material covered here, since it specifically concentrates on aid to "the justice sector" aimed at human rights objectives, and this is also the principal focus of a substantial proportion of the projects under review. The International Council's main findings were that if done well, human rights aid to the justice sector can have an important positive impact, but conversely, poorly thought 
out and executed assistance can actually be harmful. The study proposes four main criteria for determining if aid programmes have the potential to be successful: "on the degree to which human rights are integrated into the development process as a whole; on the adoption of a strategic approach; on the establishment of effective and honest partnerships that recognise the authority of beneficiaries to direct reform efforts; and on careful attention to challenges that particularly affect the justice sector". Each of these criteria incorporates a range of specific and detailed recommendations, some of which will be drawn on in the analysis below.

Adding to their relevance as standards of assessment for this research project is that fact that some of the perspectives emerging from the International Council study were echoed in the interviews conducted for this project with Chinese legal practitioners and scholars, the majority of whom had been involved in some way in donor projects ${ }^{13}$. In particular, Chinese informants concentrated on the need for effective strategy based on greater control of programme agendas and specific projects by recipients, and on more understanding of both actual needs on the ground in China and of the political context, as well as on a broader conception of human rights than most donors had adopted.

10 First this article describes the context for these programmes, starting with an introduction to the approaches of the donors under study and a brief assessment of rule of law as thematic focus. It goes on to explore a number of specific issues related to strategy: the question of strategic planning, both on the part of donors and the Chinese government; the commitments made on both sides to these programmes, including funding levels for law and rights programming; potential and actual harm associated with donor projects; levels of contextual knowledge among donors and how much is learned from experience; the question of how needs are identified and by whom; and the issues of substantive focus, choice of partners and co-ordination among donors. The article concludes with some thoughts on how donors could improve their programming.

11 The concerns raised here should not obscure the fact that, while some were wary of making generalisations, overall those scholars and practitioners in China involved in donor-funded legal projects and exchanges felt they were beneficial to both sides involved. One such benefit was exposing people outside China to the realisation that views within the country on human rights were not monolithic, according to a Chinese informant. The more constructive engagement there was on this topic, the less the Chinese government would feel threatened by human rights-related activities, this Chinese scholar said. There is certainly a need for foreign support for human rightsrelated legal programmes, and the political space for programmes that can have an important positive effect in encouraging and supporting individuals and groups that are committed to bringing about improvements in respect for human rights has expanded in recent years. But as the analysis below indicates, there is also an urgent need for much more strategic thinking about how this may best be done.

Donor approaches

The Western donor programmes studied here generally focus on strengthening "rule of law" in China. In part, this approach is part of a broader strategy among aid donors globally to concentrate on "strengthening" this aspect of what they term "governance" ${ }^{14}$, linking it to both economic development and democratisation ${ }^{15}$. Thus, generally rule of law is not presented as a stand-alone goal in donor objectives, but is linked in with 
other aims ${ }^{16}$. There is a deep-seated-and possibly erroneous-assumption that the kind of changes advocated under the rubric of "governance reforms" will inevitably lead to improvements in protections for human rights ${ }^{17}$. Some commentators question whether aid to "rule of law" may even be able to achieve less narrowly focused objectives:

Thus far the field of rule-of-law assistance has expanded less because of the tangible successes of such work than because of the irresistible apparent connection of the rule of law with the underlying goals of market economics and democracy that now constitute the dual foundation of contemporary international aid..$^{18}$

In the China context, the rule of law has been a key element of the broader bilateral aid programmes of the countries under consideration, many of which make supporting the development of a market economy in China through economic reform a principal focus. Multinationals headquartered in the West have a strong interest in China developing a legal system that can protect their investments, and this concern may be the most important reason why Western governments are keen to contribute to this aspect of China's development. An official of the Australian Human Rights and Equal Opportunities Commission (HREOC) ${ }^{19}$ linked Australia's human rights co-operation with China to constructing a legal system in China that would facilitate trade, saying that China's commitment to this objective made co-operation easier ${ }^{20}$. Australia's possible interest in legal reform for the same reason was not mentioned.

Despite commitments to human rights as an objective of aid policy, in the case of many of the countries under review here, integrating human rights into overall development aid policy often seems more rhetoric than reality when it comes down to the practicalities of working out a programme in a country like China ${ }^{21}$. The donors studied here either do not prepare strategy papers that provide analysis of China's human rights issues and how the interventions donors are supporting address them, or incorporate human rights only in a very broad and general way into overall development co-operation strategy papers ${ }^{22}$. Overall, donors make little or no reference to or use of the information on human rights issues in China generated by the UN mechanisms ${ }^{23}$. 


\begin{tabular}{|c|c|c|c|c|c|}
\hline $\begin{array}{l}\text { counary } \\
\text { ox reglen }\end{array}$ & 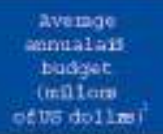 & $\begin{array}{l}\text { tears } \\
\text { the } \\
\text { wet budpet }\end{array}$ & $\begin{array}{l}\text { Averge } \\
\text { aimualist: } \\
\text { Drlax o rfits? }\end{array}$ & 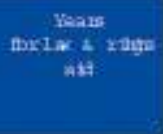 & $\begin{array}{c}\text { Lave fe retro } \\
\text { as } \\
\text { of tan }\end{array}$ \\
\hline Austnata & 289 & $1997-2001$ & $0593000 ?$ & $1997-2002$ & 2051 \\
\hline chenasa & 372 & 15282000 & 2 & 19282003 & $5 \times 6 \times$ \\
\hline beana ak & 2 & $1597-2050$ & $1^{4}$ & $1927-2002$ & $50 \mathrm{~s}$ \\
\hline Pianon & 4) & $1097-3000$ & 1. 2 & $1990-2003$ & 34 \\
\hline gema dy & $305: a$ & $1997-2000$ & $1.5^{5}$ & $20-00-2003$ & Q Eas \\
\hline sethe it nde & 20 & $1997-2006$ & 0,83000 & $1001-2003$ & 4.2 F \\
\hline Nosray & 12.7 & $1997-2000$ & $0.520=00^{\circ}$ & $1998-1003$ & 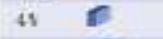 \\
\hline Sreaen & a.9 & 19272001 & $0.882000^{7}$ & 12962003 & $=$ \\
\hline Unita Kingos & K1 1 & 19220000 & $6234200^{\circ}$ & $1992-2004$ & 139 \\
\hline $\begin{array}{l}\text { Rurquear } \\
\text { onicot }\end{array}$ & 88 & $1958-2003$ & $\begin{array}{l}8.5 \\
0.99000)\end{array}$ & $1998-2003$ & $\begin{array}{l}958 \\
1051\end{array}$ \\
\hline
\end{tabular}

NB : 1 Figures for spending on country programs are from OECD Development Assistance Committee, 'Net disbursements of ODA to individual recipients', in Geographical Distribution of Financial Flows to Aid Recipients 1993-1997, 1999, and the same publication for 1996-2000, published in 2002. In the additional years provided for Australia and Sweden, information is from their respective international development agencies. Figures for the EU are from European Commission, 'Annex 5: Main figures and estimates-EC cooperation 1998-2005', in Country Strategy Paper: China 2001-2006, p. 39.

2 Figures in this column are not strictly comparable, as in many cases funds were spent primarily on general legal training and not on rights-specific projects.

3 This figure represents annual budgets for HREOC (Australian Human Rights and Equal

Opportunities Commission) plus some funds disbursed by AusAID in the form of grants to

Chinese organizations

4 Information supplied by the Danish Embassy in Beijing.

5 This is a rough estimate based on figures available for GTZ (German Technical Cooperation

Corporation) projects and an interview with German Justice Ministry, June 30th 2003.

6 This figure represents spending on NCHR (Norwegian Centre for Human Rights) projects only.

7 This figure represents spending on RWI (Raoul Wallenberg Institute) projects only.

8 This figure represents spending on the Human Rights Project Fund only.

9 The larger figure represents totals for declared spending on all law and rights related projects. However, the EC claims that $12.6 \%$ of total aid spent on 'rule of law and human rights'. The figure in brackets is spending on projects with a specific focus on human rights

16 Where human rights is mentioned as a focus for co-operation with China, the reference is generally exclusively to civil and political rights, with added attention to be paid to the rights of women, children and minorities. Virtually without exception, the legal cooperation programmes do not address economic, social and cultural rights-although these have been covered in trainings on international human rights law supported by the Nordic countries-as donors assume that traditional development programmes take care of this area. Where concern is expressed about the growth in inequality in China in recent years ${ }^{24}$, this awareness does not appear to be applied to legal or human rights programming. There has been almost no effort to think through how the extreme inequality that most donors say is now among their primary concerns is reflected in the legal system.

The rule of law focus has led to a wide variety of donor approaches. The main methods include study tours, input from international experts, joint research projects and training inside and outside China, ranging from a few days to studying for academic degrees. The programmes studied here can essentially be divided into two main categories: those based on comparative law "modelling" and those focussing on international human rights law. Most of the programmes are in the first category, presenting Western practice as a model for China to follow. Thus France and many other donors have concentrated their programmes on improving the quality of legal professionals through training, with the primary focus being on laws governing the 
economy. Germany has focused mainly on detailed technical assistance with specific areas of law, also concentrating on commercial and financial law, and more recently, a substantial number of projects on administrative law. Another approach still based on modelling, exemplified by Canada, the Netherlands, the UK and the EU, has been to put the bulk of funding into generalised legal programmes, while providing some support for work in the area of criminal justice and a few specifically human rights focused projects. Australia has concentrated its funding on projects relating to the criminal justice system, working almost exclusively with government agencies.

18 The programmes of the Nordic countries are mainly in the second category. Although their starting point was also "legal exchange", Denmark, Norway and Sweden have consistently concentrated on international human rights law as their main entry point. The combination of a set of agreed rules that apply to all-international human rights standards-and a clear goal-building up education on the law that articulates those standards-certainly qualifies as a more strategic approach than those of the other donors studied here. It is also one that emerges from the specific expertise that the Nordic countries have to offer to a country like China, and thus does also incorporate some degree of modelling and comparative work.

Donor programmes also differ greatly in the method of project implementation ${ }^{25}$. However, in most cases the country's foreign ministry or international development agency allocates money, sometimes through a competitive bidding process, to domestic implementers to run projects in China. In the cases of the Nordics and Australia, one major implementer is essentially responsible for the whole programme ${ }^{26}$, while the UK and Germany have several established agencies conducting the work, and Canada mainly channels money through a handful of domestic institutions. The EU has established special project implementing bodies for its major projects, but also gives grants to European and Chinese agencies for smaller projects. The Netherlands is an exception in taking a hands-off approach, providing its funding through a grant-giving programme which gives money to Chinese institutions for specific projects.

In the main, neither the Chinese side nor the donors have set clear objectives for the programmes under review ${ }^{27}$. The general approach to achieving what goals are set is engagement, both through the dialogue and through co-operation-the co-operation approach centres on exchange, and is thus not specifically focussed on changing Chinese reality. On the donor side, however, the co-operation is based on the underlying assumption that China is committed to improving human rights, and can be helped to do so through projects that, in a variety of ways, increase Chinese knowledge of solutions to human rights concerns in the dialogue countries ${ }^{28}$, as well as in international human rights law ${ }^{29}$. Obviously it would be neither wise nor useful for donors to set goals absent any commitment to achieving them on the Chinese side. Where aims in terms of improving human rights are specified by the donors, these are very broad and general-and in some cases, ambitious ${ }^{30}$. Others assume that human rights objectives are inherent to the rule of law agenda and need not be spelled out ${ }^{31}$.

21 On the donor side, it is mainly in the context of the human rights dialogues that statements about the overall policy are made, with comments about the need for "practical results" being a common refrain. However, most donors also subscribe to the view that the main effects of these programmes will only be seen in the long term.

22 Project planning by implementing agencies is more detailed and sets clearer objectives since they have to justify what they are doing to the donors. In general, implementers' 
goals are more modest than statements by donors. However, some implementers tend to exaggerate the extent of positive developments in China and claim more credit for them than might be warranted by the extent of their involvement ${ }^{32}$.

The relative importance of China in the aid policies of the countries studied here varies widely. Germany is China's largest bilateral aid donor after Japan, giving sums that dwarf the contributions of other donors. China was among the top three recipients of Canadian aid in 2000-01, in Australia's top five individual aid-receiving countries for the last six years, while it was in the top 20 for the United Kingdom. By contrast, Denmark, Norway and Sweden give a relatively low priority to aid to China, as they all concentrate their aid on a selected group of what are sometimes known as "programme" countries that are among the world's poorest. However, due in part to the traditional emphasis of the Nordic countries on human rights in their foreign policy and pressure from public opinion, for both Norway and Sweden the engagement with China is a major focus. France concentrates its aid on poor countries in its "priority solidarity zone", which does not include China. Given its size, China ranks low down as a recipient of EU aid ${ }^{33}$.

"Rule of law" as entry point

Rule of law theorists may simply expect too much from law... Instead of reflexively requiring that China immediately adopt the institutional attributes of a mature legal and judicial system operating in a mature constitutional culture and advanced economic environment, rule-of-law theory needs to think a lot more about what special conditions and needs face developing as opposed to developed societies. ${ }^{34}$

Donors consistently describe their programmes as covering the "rule of law", but in fact the Chinese side did not accept this appellation for these bilateral programmes, preferring to describe what was being done as "legal co-operation" or "legal exchange". This indicates that the Chinese government is well aware that Western donors tend to see rule of law not in a narrow, technical or "thin" sense ${ }^{35}$, but as part of the framework of liberal democracy.

"Rule of law" is a highly contested term, both in China and in the West, a fact rarely acknowledged by donors. As Tamanaha puts it, rule of law is like the notion of "the good", in the sense that "everyone is for it, but there is no agreement on precisely what it is" ${ }^{36}$. Since there is no agreement among scholars internationally about what rule of law means, it hardly comes as a surprise that what donors think they are talking about and what their Chinese partners are aiming for through these programmes may be very different.

Despite the official endorsement of the idea of "ruling the country in accordance with the law and establishing a socialist rule of law state", adopted by Jiang Zemin in 1996, incorporated into the communique of the Sixteenth CCP Congress in 1997 and into the national constitution in $1999^{37}$, the debate over the aims of legal reform in China continues to rage. Even those who are optimistic about the direction of China's legal development do not necessarily see it as moving towards embracing a liberal understanding of rights. The evolution of a number of countries in the region with highly developed legal systems supports such scepticism. As Jayasuriya writes, "[I]n East Asia, the rule of law-contrary to what is assumed in the liberal paradigm-can serve to entrench and consolidate public or state power" ${ }^{38}$. Some scholars argue that constructing a legal system is an attempt by the Chinese ruling elite to forestall democratisation and maintain their hold on power ${ }^{39}$. 

who are working towards greater respect for and protection of human rights through law. And of course, it is far from certain that the Chinese leadership will be able to control the eventual outcome of legal reforms. The lack of a conclusive view on the direction of reform should not preclude international involvement. As the International Council study emphasises, even when government's "commitment to reform is very weak", there are useful things aid can do, such as supporting reform constituencies and strengthening unofficial institutions, although even then donors should not abandon work with official bodies ${ }^{40}$.

However, other factors call into question an exclusive focus on rule of law as an entry point to working for human rights goals. First, the track record of rule of law assistance elsewhere-even given a greater level of commitment from recipient and donor governments-is not encouraging ${ }^{41}$. Part of the problem may be that the gap between expectations and reality is often too wide: "Rule-of-law programmes in developing countries are burdened with expectations that far exceed those placed on development programmes in richer nations in a previous era" ${ }^{42}$. A key question is how much legal professionalisation and institution building can achieve in the absence of government adherence to the normative values that are the stated or unstated objectives of donor programmes. Studies of aid to legal reform show that an overly technical approach may achieve little as it does not address the fact that certain deficiencies of legal systems serve powerful interests, and thus there may be no incentive to change them ${ }^{43}$. Also, the assumption that improvements at the highest levels of the legal system will automatically trickle down to lower levels may have as little foundation in reality as the economic version of this idea. The combination of highly competent legal institutions in capital cities and dysfunctional ones captured by local elites at the periphery is not a phenomenon unique to China, but common to many developing countries ${ }^{44}$.

Second, the formal legal system may not be the most appropriate route to addressing some of the particular problems donors are concerned about. An example is the likely impact of efforts to improve professionalism in China's criminal justice system. Hualing $\mathrm{Fu}$ argues that given the priority accorded to "stability" and the fight against crime, in fact the operation of the courts in this area is most closely in accord with existing law, and thus the most "professional" and least corrupt judged by the internal standards of the Chinese legal system ${ }^{45}$. In the areas of civil and administrative litigation, the establishment of a formal legal system may actually increase the costs of justice for the poor, and make it less accessible for them ${ }^{46}$. In China today, many of the most difficult cases are taken on by "barefoot lawyers" without any formal training ${ }^{47}$, while large sections of the population in rural areas rely mainly on "legal workers", not lawyers, for legal advice ${ }^{48}$. Qualified lawyers in some places are seeking to bar such paralegals from representing clients or providing legal advice ${ }^{49}$.

Furthermore, the focus on the formal legal system does not necessarily reflect how rights are asserted in society. For example, in China rural protesters frequently use laws and regulations to support their arguments, but rarely consider going to court ${ }^{50}$. Such phenomena raise broader questions about the embeddedness of legal institutions in society. As a Carnegie Endowment seminar on law reform concluded, "If law reform is merely a social tool... [it] must arise from or be founded on underlying social change, or endogenous demand. For some areas, such as human rights for unpopular ethnic

China Perspectives, 51 | january-february 2004 
minorities, external pressure on either the public or government may be the most effective starting point" ${ }^{51}$.

Lack of strategic planning

Much assistance for justice reform has been poorly planned and coordinated. Reforms would be more effective if both donors and beneficiaries adopted a more strategic approach. At national level, clear national policies and plans should be formulated. Donors should assist these efforts. They should coordinate their activities better, avoid duplication, and improve their understanding of local needs. 52

In the programmes under study here, the kind of strategic planning advocated by the International Council has mostly been notable by its absence.

The incorporation of "ruling the country in accordance with the law and establishing a socialist rule of law state" into the constitution in 1999 is often cited by donors as a basis for their work in the field. But this constitutional change has not been followed up with any road map for reform: the Chinese government has not developed concrete plans for reform of the justice sector, for making human rights improvements, or for the legal system as a whole. Many legal professionals have been calling for the establishment of some sort of planning process for legal reform for some time, as they believe that in the legal system piecemeal and often conflicting reforms may sometimes do more harm than good.

For the moment, the only plans available are routine documents issued by individual ministries or departments ${ }^{53}$. In the main, these are not focused on achieving overall goals for the legal system, let alone for human rights, but on the development of the particular institution in question. While such plans may provide a good basis for cooperation with one of these institutions, they do not identify the needs for the system as a whole.

Donor governments do not appear to have offered to support official planning processes for legal reform, or criminal justice reform, as they have done in other countries $^{54}$, nor have they tried to reach agreement with the Chinese government on benchmarks that might be achieved through co-operation programmes. One reason may be the assumption that because China is not aid-dependent donors have little leverage. Although the Office of the High Commissioner for Human Rights has raised the issue ${ }^{55}$, governments engaged in dialogues with China have not tried to encourage Peking to formulate a National Human Rights Action Plan, as all governments agreed to do at the Vienna World Conference on Human Rights in 1993, let alone offered to fund the process ${ }^{56}$.

Low levels of commitment

5 Governments are only likely to make clear plans when they are committed to justice reform. This element of a strategic approach will be considered on three levels: the first will be to look at the level of domestic commitment to the kind of goals being pursued by donors; the second, to examine the basis for co-operation agreed with the dialogue countries; and the third, to explore the environment for co-operation as a reflection of both of the first two factors.

"When compared with the efforts made for economic reform, the central government's attitude towards judicial reform seems to reveal a lack of commitment", one Chinese scholar writes ${ }^{57}$. While a full assessment of the current state of legal reforms in China and of their potential impact on human rights conditions there is beyond the scope of 
this article, many legal scholars inside and outside China feel that currently the main barriers to further institutional development (and human rights improvements) are essentially political in nature, whether allowing real judicial independence, the allocation of resources, or breaking log-jams created by institutional rivalry by making decisions on hard questions about division of responsibilities. As Peerenboom puts it, "[T]he major obstacles to rule of law in China are systemic and institutional in nature" ${ }^{58}$.

Many of the Chinese scholars interviewed identified the principal barrier to the protection of human rights in the criminal justice system and more generally as being political will, with the main blockage being the lack of political reform. Cultural attitudes were also cited as an obstacle to change that would take a long time to shift. One academic argued that one of the main constraints was lack of resources, which would be needed to construct the legal system that was an essential prerequisite for the protection of rights.

The weakness of law implementation is an example of the way institutional barriers are blocking progress. As Chen writes, "The involvement of a multitude of organisations and factors in the implementation of law means that difficulties and problems encountered by law-enforcement agencies in the process of the implementation of law are often caused by a number of factors or a number of institutions. More importantly, and logically then, efforts undertaken by individual authorities will not resolve these problems"59. Even within one institution, the piecemeal approach to reform may have undesirable results. Li argues that despite the many reform measures tried by the courts, "because of the lack of a framework design, it seems that some measures are not coherent and indeed are sometimes conflicting... when reform has reached a certain stage it is necessary to have a clear goal and coherent design for further change" ${ }^{60}$.

At the bilateral level, the difference over the "rule of law" label is just one indication of the fact that in terms of joint commitment to a common set of objectives, the programmes under study began on a weak basis with little in the way of specific agreement between the two sides as to what the co-operation would entail in practice. In all these donor programmes, co-operation in the field of human rights was launched from a minimalist platform of "legal exchanges" agreed in human rights dialogues or other diplomatic interactions. In the case of the UK, legal exchanges had already been underway for some years ${ }^{61}$ and were thus a logical choice, while the work of private foundations, most notably the Ford Foundation, was frequently seen as a model for combining a focus on rights with work on law.

In a 1999 assessment of Swedish human rights training programmes in China, Mellbourn and Svensson identified a lack of shared objectives as problematic and called for more frank and open discussion between the Chinese and Swedish sides about the nature and aims of the programme ${ }^{62}$. Currently, only in the Australia-China human rights dialogue and the German-Chinese rule of law dialogue are specific co-operation programmes regularly discussed. Some representatives of donors and implementing agencies thought that it was better this way, as the dialogues were overly politicised events with little real substance involving people who knew little or nothing about the practicalities of co-operation.

41 Even after the agreement to co-operate, most Chinese officials remained allergic to mention of human rights as a focus of the co-operation, and to some extent this continues to date. For example, staff of the Australian HREOC said that while initially, 
Chinese officials did not accept that they had any human rights problems that could be dealt with through the co-operation, they now acknowledge that Australian assistance may help resolve certain deficiencies in their legal system. But these are not framed in terms of human rights, and therefore HREOC "rarely use[d] the human rights term in response"63. According to Sweden's Raoul Wallenberg Institute, if the term human rights is mentioned in descriptions of projects that involve foreign participation, the organisers may run the risk of cancellation ${ }^{64}$. The continuing sensitivity of the term is highlighted by the fact that the Canadian International Development Agency had originally planned to drop the term "human rights and democratic development" from the new country development policy framework now under preparation, and refer only to "good governance", the goal of which would be to "support Chinese efforts to increase rule of law as a means to uphold the rights of its women and men"65. After the proposed change met with an outcry from Canadian NGOs, CIDA backed down ${ }^{66}$.

Another indication of commitment levels is the fact that many of the projects still take place in a very difficult environment, despite the upbeat tone of most donors' public statements. In the Chinese bureaucracy, there is still considerable hostility and suspicion to foreign co-operation in certain quarters. For example, local authorities ordered that the proceedings of a 2001 three week Nordic workshop in Jilin province for Chinese law teachers on international human rights law be videotaped ${ }^{67}$. "Anything involving international elements and human rights in China is still very sensitive", said one Chinese scholar, while another said foreign involvement in law per se remained sensitive. Foreign funding was less of a problem than foreign participation, especially if the project involved examination of conditions on the ground, added another.

Academics have consistently been less scared of centring co-operation around human rights-although in practice the work done has often stayed on a fairly abstract leveland this is one reason why many donors are more inclined to focus their co-operation on work with them. Chinese academics engaging foreign counterparts on human rights and researching the subject was an aspect of the official response to the isolation China suffered after the 1989 massacre ${ }^{68}$. This does not mean that scholars are free to engage as they wish, however, as the incident described above shows. Teachers who lecture on international human rights law have to be aware of the fact that students may be reporting on what they say in class to the authorities, and this can get them into trouble. A statement by an official in a rare article on foreign aid in China published in a popular Chinese magazine presented a paranoid view of donor engagement with academics:

There is no free lunch in this world. If the other side needs to find out something, they support your experts to do a study, to do some research, and when it is done, they take all the material away. Some of these things the government doesn't even know about... The origins of the figures some scholars use are problematic, they are not very accurate; some should really be considered estimates, but they don't even check them and just put them out. This can have a really bad effect, and can become a human rights bomb that is used against you. ${ }^{69}$

Despite their clear focus on international standards, the three Nordic human rights institutes' work has not been without difficulty. While the climate for human rights research and education in universities has certainly improved in recent years, the field remains hemmed in by political restrictions. A university lecturer prefaces his human rights course with an admonition to students not to choose to specialise in this field, since "...it is morally embarrassing, economically unprofitable, politically dangerous 
and academically difficult" 70 . In addition, "there is... the problem of scarce financial resources and a pressing need for educated legal personnel in other areas of law. Students have difficulties seeing any use in deepening their knowledge of human rights law since there are very few career opportunities for experts in the field in China. Chinese law teachers engaged in human rights law research are used to keeping a low profile and often work without any administrative or financial support from the university authorities" ${ }^{71}$. However, since this comment was written, the situation has started to change, as universities compete to set up human rights centres-five were set up just in the past year ${ }^{72}$-and find donor funds to support them. Domestic funding, however, is generally still unavailable ${ }^{73}$. There are initial indications that student interest in human rights courses is rising ${ }^{74}$.

Considered in purely financial terms, the relative priority accorded to law and rights programming in China does not match the rhetorical weight many of China's dialogue partners give to this co-operation (See table). The limited nature of the human and financial resources available makes the question of appropriate strategy even more important. For the majority of donors covered here, law and rights projects represented well below $5 \%$ of their overall aid programme in China, although Canada, Denmark and Sweden were all above this level. In China much more money is spent on aid to legal projects relating to the economy, commerce and finance than on human rights-related projects ${ }^{75}$. This is not unique to China: aid spending on human rights globally is low ${ }^{76}$. For example, between 1995 and 1999, under 1\% of the EU's external aid budget went to "human rights positive measures" 77 .

of course the low level of funding also reflects commitment on the Chinese side, particularly the relatively restrictive climate for such programming and the small number of Chinese partners willing to take it on. Other factors include the limited capacity of some of the implementing organisations in donor countries, where the learning curve for engaging effectively in such programming can be steep ${ }^{78}$. Some development agencies have engaged in such work reluctantly, under pressure from politicians. Knowledge of human rights issues among staff of development agencies may be limited, while the complex nature of many interventions in this field could be intimidating. Measuring the impact of programmes aiming at improving human rights and promoting democratisation is considered difficult ${ }^{79}$, and thus the shift to resultsbased management of projects many donor agencies have made in recent years may militate against taking up such work.

Bad aid can harm

47 An additional reason why a strategic approach is needed is one highlighted by the aid recipients interviewed for the International Council study. Bad programmes are not necessarily just a waste of time and money, but may actually do harm: "Badly conceived and implemented programmes have sheltered repressive regimes from scrutiny, wasted vital resources, distorted domestic institutions and fostered social division" ${ }^{80}$. By contrast, comments on bilateral programmes focused on law in China have generally assumed that there can be no downside to such assistance ${ }^{81}$.

In the China context, it is hard to make an assessment of whether programmes and projects in this field have caused harm, or have the potential to do so, since they have been little studied so far. But there are several areas where there is significant cause for concern: the impact of the programmes on overall policy towards China; lack of 
attention to monitoring; the focus of some specific projects; and the impact of donor agendas on certain fields of academic research.

A number of critics of the dialogue and co-operation approach have argued forcefully that this policy has led to diminution of international scrutiny of China's human rights record. While examination of this point is beyond the scope of this study, some comments on the mix of policy options chosen are important to the question of strategy. The International Council study concludes that while trade-offs between legitimate criticism and co-operation should not be made, co-operation should be pursued "except in cases where the government concerned explicitly rejects and blatantly violates international human rights standards"

Chinese informants agreed on the need for both co-operation and pressure, and were not aware of the trade-offs that these programmes often involve. Virtually without exception, Chinese scholars interviewed stressed how important international pressure had been and continued to be in pushing the Chinese government to make human rights concessions and improvements. But they found it difficult to articulate what pressure should actually involve, evincing a certain degree of discomfort about criticisms of their country. Some pointed out that sometimes pressure could also have negative effects, creating resistance to change among the powers that be. One asserted that pressure should be used in a way that didn't make the Chinese government lose face.

51 Such comments point to a need for sensitivity to the context and for greater understanding about specific human rights issues, and this requires human rights monitoring. Good information can be generated by a range of different actors-both domestic and international-as well as donors themselves. This means donors should support monitoring, as well as do it, and this is particularly important in the China context, where quality information on human rights conditions remains very limited, due to severe restrictions on domestic human rights monitoring. But very few of the donors studied here have supported work specifically monitoring human rights conditions, with almost all excluding the work of groups and individuals working outside China ${ }^{83}$. As the International Council study points out, monitoring the progress of reform is also crucial to determining how interventions are working and what kind of projects work best.

52 While these types of actual or potential harm are more in the nature of acts of omission rather than commission, a few examples can be cited in which donor approaches may have created problems more directly. One example is the three training sessions at which Australian officials instructed Chinese Ministry of Foreign Affairs (MoFA) staff on reporting under the two UN covenants ${ }^{84}$. MoFA is essentially responsible for presentation of China's information in the best possible light, rather than the monitoring of human rights conditions that should be a part of preparing a report under a human rights treaty. Australia did not invite any UN staff or members of treaty bodies to participate in these trainings, let alone any NGOs ${ }^{85}$. Recently, Chinese Foreign Ministry officials said that they were getting better at treaty body reports "so we won't be criticised" ${ }^{86}$. This is hardly the desired outcome of such "training".

53 Another example is the way donors may have contributed to resistance to reform on the part of some officials in the procuracy by an over-concentration on support to courts and on projects that enhance the authority of the judiciary ${ }^{87}$. However, a number of donors now have projects with the procuracy in China ${ }^{88}$. 
incentive structures. For example, the Chinese Academy of Social Sciences has been known to demand speaking fees for its own staff at conferences it is convening with donor funds. One implementer complained that some provincial women's federations just saw donors as "money bags" and didn't care much about the substance of the projects ${ }^{90}$.

57 Finally, many projects are merely wasteful in a context where resources are scarce. Mostly the problem appears to be shifting donor priorities, which result in what might be termed "hit and run" projects. The most extreme example of this is the Australian programme, which is essentially a series of reciprocal study visits with a large number of institutions mostly unconnected to any practical outcomes or specific reforms. Some of the largest projects also suffer from short-termism. A key example is the EU's largest rule of law project, the EU-China Legal and Judicial Co-operation Project, in which the main activity was extended study visits of Chinese legal professionals to Europe ${ }^{91}$. Enormous energy went into establishing the project, with its own office in Peking and a high production value website, but after only four years of operation and one round of research grants, the whole structure is being abandoned. To be sure, some say that the money could be much better spent on promoting basic legal education in China ${ }^{92}$, so there are arguments for not continuing such an expensive form of training, but this is not the reason why the project is not being continued.

Contextual knowledge, transparency and learning

important element of strategy is knowledge: understanding the context, making information about projects available to others and learning from experience. This is related to the issue of monitoring. In a paper on "rule of law" aid, Carothers highlights a lack of knowledge in this area of aid more generally:

The rapidly growing field of rule-of-law assistance is operating from a disturbingly thin base of knowledge at every level-with respect to the core rationale of the work, the question of where the essence of the rule of law actually resides in different societies, how change in the rule of law occurs, and what the real effects are of changes that are produced. The lessons learned to date have for the most part not been impressive and often do not actually seem to be learned. The obstacles to the accumulation of knowledge are serious and range from 
institutional shortcomings of the main aid actors to deeper intellectual challenges about how to fathom the complexity of law itself. ${ }^{93}$ serious shortage of accurate information about the functioning of the legal system ${ }^{95}$. A key example is the serious inadequacy of statistics on the operation of the criminal justice system, with such figures as the number of executions per year still being considered "state secrets". Several of the more knowledgeable people working in implementing agencies complained about the lack of time and money devoted to the learning necessary for their jobs. Some Chinese informants expressed frustration at the lack of knowledge of the China context, particularly the political context, among people working for some donor agencies ${ }^{96}$.

61 Such a lack of empirical knowledge is a common shortcoming of legal and judicial reform programmes:

The story of legal and judicial reform is one of modest successes... and frequent failures, and of significant gaps between theoretical understanding of legal systems and project design and implementation. The gap between theory and practice stems from a number of pressures... It points to the crucial need for investment in empirical approaches to legal systems development and to the invidiousness of the distinction that some in the development community make between action and research. ${ }^{97}$

62 An important part of the accumulation of knowledge is evaluating work that has been done. But few evaluations of China projects have been done, and some donors mentioned that Chinese partners did not like evaluations. ${ }^{98}$ In many cases, there has not been sufficient follow-up on donor projects ${ }^{99}$. This lack of attention to evaluation and accumulation of lessons learned is also a common feature of assistance elsewhere ${ }^{100}$. One reason for the lack of learning is the strong pressure for success in law and rights work in China. The linkage of these co-operation projects to donor government policies means that the assessments of projects is often over-optimistic. But the strong interest of implementing agencies in continuing to receive funding ${ }^{101}$ also militates against dispassionate assessment. Another reason why people lack information is that there has been insufficient attention to the circulation of donor-supported research, a point made by both donors and some Chinese informants. Official funders of scholarly research in China have not required this, so there is no tradition of doing so.

63 A further barrier to learning lessons is the lack of transparency. In terms of the programmes studied here, only the Nordics and the Netherlands were willing to share detailed project information and any evaluations with the author. Australia, Canada and the UK apparently have no provisions for public reporting on how aid money in this area is spent. Information provided by France was minimal, to say the least. While transparency rules for the EU are better, since none of the large projects under study are completed, written information assessing their progress is not available, although for some projects there are basic reports on some activities ${ }^{102}$. Extensive information is provided on Germany's legal technical assistance projects implemented by GTZ, ${ }^{103}$ but little on other projects. 
Transparency was an issue of concern to Chinese informants. Scholars outside the circle of those involved in aid-funded projects expressed frustration at the lack of information about what these were focusing on and how they might apply for funding, and even some of those receiving funding spoke of donors' preferences as being "a black box". It would be better if the donors could make public the scope of their giving activities, and open the process up to applications. Some assert that donors tend to work only with people who speak their language, in both literal and figurative senses. A small handful of scholars get large amounts of money, said one informant, with obvious resentment. Confirming such a view, another asserted that it was "easy" to find donor funding for human rights- and rule of law-related projects.

Ownership and identification of needs

The International Council study identifies local "ownership" 104 of programmes as a key element of success-if projects are driven by donors' concerns and political agendas, they will not be likely to achieve much.

6 The process of identifying projects in China has generally meant a lot of legwork by representatives of donors to find appropriate entry points. In most cases, personal contacts had already been made-often related to China's efforts post-1991 to begin some engagement on human rights issues-that yielded some initial activities. To start with at least, Chinese partners appear to have been unwilling to identify gaps in knowledge or deficiencies in practice that co-operation programmes could help to address. To some extent, this remains a problem today.

Representatives of implementing agencies acknowledge that it has often been difficult to engage Chinese partners in identifying their needs and to encourage them to take the initiative in proposing projects. This is clearly due in part to the sensitivity of the subject matter, and the lack of commitment on the Chinese side, since Chinese partners evidently feel that while they know co-operation is acceptable, they are not sure what its scope should be. But there are also other factors: for example, it is often the foreign affairs departments, rather than the people working on the substantive issue in question, who discuss and negotiate projects with donor representatives ${ }^{105}$. In addition, the rubric of "co-operation" evidently means that the needs of both sides must be accommodated, and engagement of home country nationals and institutions in aid programmes is generally an acknowledged donor objective for aid policies ${ }^{106}$. Justifiably, Chinese partners see co-operation not as aid, but as exchange, in which the fact of working together may be more important than what gets done ${ }^{107}$. Also, if most of the budget for a particular project is spent outside China, this understandably diminishes the commitment of Chinese partners.

Until recently, when the Raoul Wallenberg Institute asked academics what they would like to do in terms of co-operation in the human rights field, they would turn the question around and ask what RWI would like to do. Officials from the Shanghai procuracy were bemused by RWI's insistence that the focus of the training materials should be on Chinese problems, as they wanted to do a book series on Swedish law ${ }^{108}$. Despite its long history of working in China, it has been a struggle for RWI to involve Chinese partners more in programme planning.

People in implementing agencies involved in British-funded projects mentioned the difficulty of getting down to projects that were specific enough to have much impact. Often years of working together on more general topics were necessary before a Chinese partner would be willing (or able) to engage in a project focused on achieving a 
practical impact on the ground. To reach this point, the necessary ingredients, one person said, were a "good working relationship" with a Chinese partner built up over several years; "a process-oriented and participatory approach moving from awareness raising of rights issues and alternative models of law and practice to the identification of a project to address a specific and defined problem"; and strong contextual knowledge ${ }^{109}$. As donors tend to be concerned mainly with "outcomes", they may not be willing to fund the kind of slow identification process that is often necessary ${ }^{110}$.

According to a European Commission official, since governance and human rights are not China's priority, the EU has to take the initiative in co-operation in these areas and "kind of impose" projects on the Chinese side. However, at the same time, he recognised that without Chinese ownership, such projects would not work ${ }^{111}$. This dilemma has clearly dogged the EU's entire co-operation programme, and has led to long delays between the launch date of projects and their actual implementation, as details of how the objectives set by the EU side can be accommodated by Chinese partners are worked out and the extensive bureaucratic requirements of the Commission systems are met ${ }^{112}$.

71 Few donors consult with Chinese experts beyond their direct partners in any formal sense on the focus of their programmes in China ${ }^{113}$. A small minority of Chinese scholars interviewed had been consulted, but most had not even thought of the idea that donors might need to pay attention to what Chinese people thought. One was very frustrated that donors did not listen to opinions from Chinese people working in the relevant fields and just had their own priorities. One who had been involved in discussions with donors on training of officials said that the main focus had been not on the specifics of the training, but asking for advice on how to negotiate the authorities' phobic attitudes towards critical comments about China. A scholar outside the circle of recipients was cynical about the motives of fellow academics who worked as consultants for donor agencies, doubting that they would say if they thought the approach the donors were using was wrong.

72 A number of Chinese informants felt strongly that donors needed to pay more attention to local perceptions of needs. "The country needs to change itself, and needs help with this. But this should be based on needs identified by people in China-not telling them what to do, or doing it for them", said one. Donors should not come with preconceptions about what would be useful based on their own system and values, and should use more Chinese consultants, said another. In their planning, donors should have more discussion with Chinese academics and officials to identify what are the real problems that need addressing, stressed another.

The Nordic human rights institutes are the only ones that have attempted to consult with Chinese people in the relevant field on any systematic basis. Examples are the feasibility study conducted by RWI in 1999-2000, and the on-going consultation with academics through the Nordic-sponsored academic meetings, bringing together Chinese scholars of international human rights law and some international experts twice annually to discuss certain human rights topics. Just in the last year, this consultation has been formalised, as the Nordics have set up an "Education Resource Group" of four Chinese academics who will provide input on their work on a regular basis ${ }^{114}$.

Focus, choice of partners and co-ordination 
74 Many donors end up working with the same set of institutions, particularly central government agencies, the National Judges College and Peking-based universities and think-tanks, as well as semi-governmental agencies, such as the All-China Women's Federation. A range of factors limit the number of Chinese institutions that can engage in the types of projects covered here, from the need for official approval to the ability to deal with donor requirements in terms of book-keeping and project management. Almost every donor has projects involving the Chinese Academy of Social Sciences Law Institute, and many also work with the China University of Politics and Law. Given the frequent failure to circulate project results and the lack of donor co-ordination, this sometimes leads to duplication of projects. There is a tendency for donors to work only with people who can speak English, as this saves time and money, but these may be the people who least need the kind of exposure which is an important part of such cooperation programmes.

75 Although human rights remains controversial in most contexts-less so now as a subject of academic study than in the past-many representatives of donors and some from implementing agencies were not aware of approval processes that Chinese partners needed to go through to work with them. However, one said that the universities they work with need to report to the Ministry of Foreign Affairs on their co-operation ${ }^{115}$. A Chinese scholar said the central government sees human rights as a "reserve domain", and does not allow provincial or local level institutions, official or academic, to work with foreign bodies on this subject without permission. Some internal regulation probably required that provincial or local institutions wishing to stage an activity of this type apply for permission from the Ministry, this academic said, adding, however, that the growing density of international interconnectedness would make it increasingly difficult for the centre to control. Almost no projects sponsored by the donors under review have been cancelled, ${ }^{116} \mathrm{a}$ fact which could either indicate that official tolerance is increasing, or that donors have not been very adventurous in their programming.

76 Scholars and practitioners outside Peking and Shanghai felt that donors concentrate far too much of their attention on those cities, to the exclusion of other areas. Not only were these cities not representative of the country as a whole, but also the concentration of donor attention made recipients blasé about it, and thus they might not put in as much energy and commitment to the projects as people in other, less favoured, areas. Questions can certainly be asked about the relative need for foreign funds of some of the institutions: for example, while many donors are doing projects to support high-level training of judges, Shanghai pays to bring in American teachers to teach judges and sends its judges to the United States for a study programme ${ }^{117}$. Guangdong is planning to establish a similar programme for its judges. The concentration of donor resources in the richest areas replicates a historical pattern in aid to China, in which, until recently, the major donors-such as the World Bank and the UN Development Programme-have acquiesced in supporting the central government's focus on developing the coastal areas, thus arguably contributing to the overall pattern of regional inequality ${ }^{118}$.

77 The International Council study identified co-ordination between donors as a key feature of successful programming. At a minimum, this is necessary so as to avoid duplication of efforts, but ideally it means pooling resources and supporting broader approaches than any one donor may be able to mount alone. But unfortunately co- 
ordination is not common: "[B]ilateral donors tend to adopt projects without a general overview of other donors' activities. In consequence their impact is only local, and in any case their choice of strategy usually reflects their own national priorities and idiosyncratic choices. For example, Sweden wants to export the Ombudsman institution; Germany to disseminate its experience in Constitutional Courts; and the United States to transplant its own civil society experience" ${ }^{119}$.

In China such co-ordination is only practiced by the three Nordic human rights institutes, which initiated co-operation to promote international human rights law teaching in 1999. For the rest, "co-ordination" is essentially limited to information sharing. In terms of the dialogue countries, meetings of the "Berne Process" initiated by Switzerland and the Office of the High Commissioner for Human Rights have brought together the representatives of the dialogue countries on an occasional basis since April 2001. Co-operation programmes are discussed, but in the main, the people directly responsible do not attend these meetings, so their utility is very limited. The Ford Foundation holds meetings of donors in the legal area in Peking once a year, and there are also occasional meetings of donors working specifically on human rightsrelated projects, but this is not formalised. One indication of the actual level of coordination is the fact that a list serve set up by the British Council as a forum for exchange among donors supporting legal projects in China was shut down last year as it was not being used ${ }^{120}$.

The lack of co-ordination can be attributed to a number of factors, including the focus on promoting national models in countries' aid programmes, the pressure for success due to the linkage to broader foreign policy goals, the desire of many donors to "be in China" and competition among donors. Such a competitive environment is a common problem in aid generally. Even in a climate of commitment to reform, such as that in Russia, donors were all doing competing judicial training projects, rather than pooling their funds to support a comprehensive training programme ${ }^{121}$. Of course it could be argued that the proliferation of different projects potentially promotes more democratic and multi-faceted approaches to reform. This might be the case if donors were primarily funding NGOs. But in addressing official rule of law building, as in the Russia case and many of the China projects, they are trying to engage with broad questions of institutional reform that require systemic solutions and large sums of money.

Some of the donors studied here could certainly make more effort to go beyond the safe circle of recipients and to support those in Chinese society who are explicitly (or even implicitly) committed to working towards achieving practical human rights goals. For example, they could provide more support for legal aid, including that provided by non-lawyers, and fund independent organisations and networks involved in specific human rights issues, including those outside the legal sphere. This might mean putting more money into funds to be disbursed as small grants with minimal bureaucratic requirements. They could also remove limitations that exclude certain types of human rights-related projects, in particular support for exile organisations or human rights projects outside China ${ }^{122}$.

81 Two Chinese scholars thought that the key area of concentration for donors should be the implementation of law. Giving money for pure scholarship was a waste, thought one informant, but donors should be more willing to support empirical studies, which were often costly. Another view was that more effort should be made to support work 
that found bases for rights in local and traditional concepts. Since academics could change people's thinking, supporting their work would be a very important component of helping China build up its own capacity to establish the rule of law and protections for human rights ${ }^{123}$. Several said that donors should be more willing to put money into improving basic legal education (not necessarily human rights related), something most seemed unwilling to do at present.

Some legal scholars were critical of the overly theoretical emphasis of much academic work in the field, which, they said, focuses too much on what is good and what is right, and not what is possible. Also, academic work may have more impact in stages of legislative reform than in the messy business of law implementation, where political commitment and broader social conditions become more important. People on the front-lines of law implementation may have better ideas about how to address real problems than academics ${ }^{124}$. However, one implementer emphasised that Chinese legal scholars have always had a much stronger role in policy formulation than their Western counterparts, so it remained important to work with them as a way of influencing government ${ }^{125}$.

Chinese informants expressed contradictory views about the potential of the international human rights law field and the contribution of donors to its expansion. The efforts of the Nordic countries to promote teaching in the field, particularly their focus on developing a network of teachers, were much appreciated by the scholars involved. An academic who was in a different field of law and one who no longer worked on international human rights law topics, however, were dismissive of what might be achieved through study of human rights in the current political climate in China, seeing no possible practical benefits from the resulting scholarship, and little scope for real academic achievements, either, due to the restrictions on what scholars in the field might research and publish.

Several Chinese interviewees felt that donors had an overly narrow conception of rights and how to support their improvement in China. According to one scholar, a broader approach was needed that addressed rights issues on the level of civic education about the role law could and should play in society. A number of Chinese informants were concerned about donors' interests in overly "political" projects. Certain donors want too much specific involvement, both in terms of substance and administration, said one.

After more than five years of human rights dialogues, privately many diplomats say that these meetings themselves achieve little, and that the real achievement of the policy has been in the co-operation programmes ${ }^{126}$. Thus, on donors' own terms, the kind of work studied here should be considered as a measure of the success of this policy approach. But the lack of clear objectives for the co-operation framed in terms of specific human rights improvements means that in general the fact that an activity took place at all is often sufficient for donors to claim success. Thus donors' reporting on the co-operation tends to be quantitative rather than qualitative in nature: how many people went on such and such a training, what kind of a seminar was staged, or the visit of a Chinese delegation to the donor country on a study tour, without identifying the actual or potential impact, or even linking the activity in question to any specific reform agenda. By contrast, reports of some implementing agencies are more likely to make an attempt to identify impacts of their work ${ }^{127}$. 

deficit is not unique to the China context; some of its effects are common features of aid programmes in the rule of law field more generally. Thus donors also need to address some broader problems, such as the fact that priorities set through domestic political and institutional processes in the donor country are not always the most useful ones in a given country context. Furthermore, the mixed motives of donorsincluding the insistence on employing home country institutions and experts, regardless of their levels of contextual knowledge or expertise and the confusion between supporting the needs of multinationals and rights-friendly rule of law-create additional barriers to achieving the human rights objectives through aid programmes.

91 the lack of attention to empirical work-including human rights monitoring-which would help to determine the most appropriate kind of interventions, and the failure to encourage and support processes of official planning at macro-level and needs identification at micro-level. Empirical approaches would lead to specific solutions aimed at concrete problems, rather than one-size-fits-all rule of law answers, which, as 
studies of aid to legal reform have found, are at best likely to be a waste of time and money. An example is judicial training: a number of authoritative studies have found that if training is not connected to an agreed reform agenda that includes incentives to change it may have little effect ${ }^{128}$. The idea that mere exposure of a few individuals to foreign models of practice can be sufficient to induce change is naïve, and has led to much waste of resources.

92 Adopting a strategic approach does not mean that donors impose their views and priorities on Chinese partners. As one implementer put it, "[T]here must be local ownership in defining the problem and how it may be solved-and then we have to welcome and accept that projects don't necessarily turn out the way we had imagined" 129.

93 Thus one of the central questions is who to engage with, particularly whether the elitefocussed approaches donors have adopted are the most likely to affect the human rights situation on the ground. Could the lengthy process of trust-building (and the necessity of donors taking the initiative to start with rather than following the lead of their Chinese partners) mean that they and other donors have been concentrating their attention on the wrong type of people and groups? What if they had begun by exploring what type of initiatives Chinese individuals and institutions were taking that could have an impact on various human rights problems-regardless of whether these are labelled as such by those working on them and regardless of what their field of endeavour is-and tried to support such efforts, both financially and through opening up international channels of communication and expertise to them?

In a society in which rights violations increasingly reflect class divisions, the degree of commitment of intellectuals as a group to addressing the sources of violations may even be suspect: "Since [1989] the government has bribed intellectuals with fat paycheques-university professors' salaries have increased by a factor of ten in the last decade. Universities and research institutes have been showered with grant money. Most intellectuals now lead comfortable lives and are allowed to publish their ideas fairly freely" ${ }^{130}$. Yet many donor programmes expect academics to be more activist in China than they are elsewhere.

Donors evidently need to put more effort into identifying areas where groups and individuals have already started engaging with human rights issues on their own and be more willing to take risks on supporting such initiatives. It is very clear that where there is already a strong constituency in China working on an issue, there is great potential. Examples are the nationwide Domestic Violence Network, currently supported by a consortium of donors, and the work of Wan Yanhai and his colleagues on HIV/AIDS issues ${ }^{131}$, as well as some criminal procedure law scholars working to introduce international standards into domestic law ${ }^{132}$. It should also be recognised that although much can be done inside China these days, there is still an important role to be played by human rights groups conducting advocacy outside the country. An example is that they are still the only ones that are able to lobby and submit shadow reports to UN treaty bodies considering reports on China's compliance with international human rights standards.

Some donors have established grant-making programmes that support more locallygenerated projects. However, these often end up funding the same semi-official agencies as other donor programmes. It would help if application processes were made 
more open and simple, and efforts were put into disseminating information about how to apply.

of course there is also value in pursuing projects with more official partners, provided they are able to address practical concerns. A positive example here is the work of a number of UK implementing agencies, funded both by the UK and by the EU, on juvenile justice issues ${ }^{133}$ and child trafficking in southwest China ${ }^{134}$.

Along the same lines, the appropriateness of the exclusive focus on the formal apparatus of law as an entry point for human rights concerns in China can also be challenged. After a frustrating experience of failure in US programmes on "administration of justice" aimed at improving legal institutions in many Latin American countries, the need to pay attention to the "demand side" is now being discussed ${ }^{135}$. In other words, if people don't demand that their rights be protected through the legal system, practices won't change. But to do this one needs to go beyond legal institutions to support such entities as community groups, bodies providing legal services to the poor, media reporting of legal processes, and so on.

In China, while such grassroots groups have been developing in recent years, they remain constrained by central and local authorities' desire to control independent organisations. This points to another element of strategy: that donors may need to engage more with the political obstacles in the way of achieving more human rightsoriented legal reform if they are serious about this kind of co-operation. Chinese informants for this study were virtually unanimous in asserting that international pressure has played an important role in contributing to human rights concessions by the Chinese government, and if there is a trade-off between the donor programmes covered here and continuing to exert such pressure, this is something they would not find acceptable. Their message was clear: people want both co-operation and continuing pressure on the government, and the two have an essential synergy. This is one reason why the terminology issue is important-making human rights work labelled as such politically acceptable potentially expands the space for domestic activism, and makes it easier for people to engage in co-operative projects on this theme.

100 Such engagement need not lead only to what the Chinese government dismisses as "confrontation", but could involve assistance and encouragement to the Chinese authorities to engage in exercises that identify their priorities in the human rights field, such as formulating a National Human Rights Plan of Action with assistance from the United Nations, employing the kind of participatory processes recommended. This could potentially open up the field of engagement and allow donor programmes to have more impact. It would serve to generate a national dialogue on human rights, which would open up space for domestic human rights advocates-arguably the most crucial aspect of achieving practical change on the ground. 


\section{NOTES}

1. The research for this article was supported by a fellowship from the Global Security and Cooperation Program of the Social Science Research Council. The Centre for Comparative and Public Law at the University of Hong Kong hosted me for the duration of the project. I am profoundly grateful to both these institutions, and particularly to Jill Cottrell, Fu Hualing, Yash Ghai and Carole Petersen for inspiration and guidance. I would also like to thank also like to thank Nicolas Becquelin and Jean-Pierre Cabestan for comments on earlier drafts of this article. Last, but not least, I would like to thank the many interviewees who were so generous with their time. Of course none of them are responsible for any errors or omissions.

2. For information on this shift, see Human Rights in China, From Principle to Pragmatism: Can "Dialogue" Improve China's Human Rights Situation, June 1998; and Ann Kent, "Human Rights: From Sanctions to Delegations to Dialogue", in Nicholas Thomas, ed., Reorienting Australia-China Relations, London, Ashgate, forthcoming, pp. 143-58.

3. In this article, the term "programme" generally refers to a country's overall approach, while the word "project" is used to describe particular activities carried out within the programme.

4. Australia, Canada, Norway, the EU and the UK have conducted regular human rights dialogues during this period. In 2000, Germany launched a "rule of law dialogue" with China.

5. France and Germany do not fit entirely into these categories, since in neither case have the legal programmes been clearly linked to a bilateral human rights dialogue. However, both countries have been among the strongest proponents of the EU-China human rights dialogue.

6. In most cases, governments and their official aid agencies only provide the funding for the projects, while the task of implementing them is given to academic institutions, specialised non-governmental organisations (NGOs), national human rights institutions, or temporary consortia of interested parties in the donor country set up for the purpose.

7. Nineteen people representing donors covered in this study and implementers of their projects were interviewed. An additional 28 representatives of other donors, scholars and human rights activists were interviewed, including 13 from China. No interviewees are identified by name, although those representing institutions are identified as such.

8. Jacques de Lisle, "Lex Americana? United States Legal Assistance, American Legal Models, and Legal Change in the Post-Communist World and Beyond", University of Pennsylvania Journal of International Economic Law, No. 20, Summer 1999, pp. 179-308; and Matthew C. Stephenson, "A Trojan Horse Behind Chinese Walls? Problems and Prospects of U.S.-Sponsored 'Rule of Law' Reform Projects in the PRC", Pacific Basin Law Journal, Vol. 18:64, 2000; and for an insider's view, see Paul Gewirtz, "The US-China Rule of Law Initiative", William and Mary Bill of Rights Journal, No. 11, February 2003.

9. This shift was linked to a number of geopolitical factors, including efforts by US administrations, in response to domestic and international critics, to improve the dismal human rights records of some Latin American dictatorships through aid; support for consolidation of democracies following a wave of democratisation in South 
America and Africa; and of course the end of the Cold War, which led to an explosion of "political aid" to countries "in transition".

10. According to Peter Burnell, "At this juncture there is simply too little known about democracy assistance in the last decade. The independent examination of it is only now beginning to approach a critical mass", while the topic has been virtually ignored by international relations scholars. P. Burnell, "Democracy Assistance: Origins and Organizations", in Burnell, ed., Democracy Assistance: International Cooperation for Democratisation, London/Portland, OR, 2000, pp. 47-8.

11. Thomas Carothers of the Carnegie Endowment for International Peace has written extensively on democracy aid and aid to rule of law programmes in recent years, see "Promoting the Rule of Law Abroad: The Problem of Knowledge", Carnegie Endowment for International Peace Working Papers, No. 34, January 2003; Aiding Democracy Abroad: The Learning Curve, Carnegie Endowment for International Peace, Washington, DC, 1999; and "The Rule of Law Revival", Foreign Affairs, Vol. 77, No. 2, 1998. Furthermore, donors such as Sweden, Norway and Denmark-which have made the strongest practical commitment to integrating human rights into their aid policies and programmes-have conducted comprehensive evaluations of this type of programming, for example, Danish aid agency Danida, Evaluation: Danish Support to Promotion of Human Rights and Democratisation, Vol. 2, Justice, Constitution and Legislation, January 2000.

12. International Council on Human Rights Policy, Local Perspectives: Foreign Aid to the Justice Sector, Versoix, Switzerland, 2000.

13. As part of this project, interviews (mostly of a formal nature, a few more informal) were conducted with 13 Chinese legal scholars and two legal practitioners. Nine of these had involvement with the type of donor-funded projects covered here, ranging from being the main representative of the Chinese partner to participation in some donor-funded activities.

14. This became a central concern of development agencies in the 1990s, particularly associated with a shift in the World Bank's approach in Africa. The lack of a clear definition of the term "governance" or of any internationally-agreed standards associated with it has led some critics to argue that it is just the latest attempt to impose technical solutions on problems that are essentially political and related to the unjust world economic order, as well as a new way of forcing countries to follow neoliberal economic policies. See Gordon Crawford, Foreign Aid and Political Reform: A Comparative Analysis of Democracy Assistance and Political Conditionality, Palgrave, Basingstoke, 2001, pp. 22-7. "The term governance may be useful in convincing recipients of the neutral, technical character of reform. As an analytical tool, however, it may obfuscate more than it elucidates" (Tom Ginsburg, "Review Essay: Does Law Matter for Economic Development: Evidence from East Asia", Law and Society Review, No. 34,2000, p. 843).

15. Carothers, "Promoting the Rule of Law Abroad", p. 7.

16. As an indication of this, as yet, there is no category for aid to "governance" or "rule of law" in the most authoritative figures for development assistance spending, those prepared by the Organisation for Economic Co-operation and Development (OECD). 17. The point made by Burnell is worth noting here: "Governance reforms that create a more hospitable climate for private enterprise and capital accumulation can also lead to great social and economic inequalities. These engender inequalities of political opportunity and, potentially, of political power too". "Democracy Assistance: The State of the Discourse", in Burnell, Democracy Assistance, p. 22. 
18. Carothers, "Promoting the Rule of Law Abroad", p. 14.

19. HREOC, which serves as Australia's national human rights commission responsible for dealing with domestic implementation of human rights guarantees, contracts with the Australian development agency AusAID to implement the projects associated with the bilateral human rights dialogue with China.

20. Caroline Fleay, "The Australia-China Human Rights Technical Cooperation Programme", unpublished paper, May 2003, citing interview with legal and human rights consultant to HREOC.

21. Some sources attest to a degree of reluctance among development agency staff to such integration, partly because human rights programming is seen as too "political" and not susceptible to the kind of measuring of inputs and outputs to which development agencies have become accustomed. See for example, Gunnar M. Sorbo and Arne Tostensen, "Aid for Human Rights and Democracy: Challenges of Design, Management and Evaluation", Human Rights in Development Yearbook, 1999/2000, p. 218; interview with Canadian International Development Agency (CIDA) staff member, April 16th 2003.

22. The exception is the UK, which prepares human rights strategy papers, but these are not publicly available.

23. To their credit, some implementing agencies have made an effort to distribute such documents to Chinese scholars. Communication from Norwegian Centre for Human Rights (NCHR), July 17th 2003.

24. Examples are the country analyses prepared by the Australian aid agency, AusAID, “Australia's Country Programme Strategy to China, 2002-5", and the UK's Department for International Development, "China: Country Strategy Paper 2002-2005".

25. The organisation of each country's aid programme is unique, and thus can be described here in only the most cursory manner.

26. And in the cases of Norway, Denmark and Australia the organisation in question is concurrently the national human rights institution.

27. Certainly objectives are set for individual projects, but these relate to completing project activities (trainings, seminars, reports) rather than to bringing about specific human rights improvements. See section on commitment for more on this point.

28. For example, the Canadian International Development Agency states that among the expected outcomes of its human rights-related projects in China are "Better understanding of Canadian values and approaches in relation to human rights, democratic development and governance in governmental and non-governmental entities". CIDA, "China Country Development Policy Framework", 1994, available at: http://www.acdi-cida.gc.ca/CIDAWEB/webcountry.nsf/VLUDocEn/ChinaProgrammemingFramework.

29. The main approach of Swedish aid overall is "to promote the influx of new ideas which may accelerate the process of reform in respect of human rights, equal opportunities, changes in the law, democracy and improvement of the environment". Swedish International Development Agency (SIDA), "Country strategy for development co-operation 2001-2005", October 30th 2001, available at: http://www.sida.se/Sida/jsp/ Crosslink.jsp?d=370\&a $=2993$.

30. An example is in the European Commission's 2001 Country Strategy Paper, China, 2001, p. 29: "[C]ooperation should focus on promoting the fundamental freedoms mentioned in the Covenants, and the implementation of legal provisions related to both civil and political, as well as economic, social and cultural rights. These will 
include respect for the individual and the fight against inhuman treatment, education, the protection of the rights of minorities, identification of particularly vulnerable groups such as women, the disabled, the poor, minorities, or children, who need assistance in asserting their rights. Consumer law and related grass-roots level legal concerns, and practical methods of legal redress may also be promoted. Special attention should also be given to public awareness of human rights". Another is from the Norwegian Foreign Ministry's China Strategy, 2002, in which the aim of the dialogue and co-operation with China is stated as being: "To improve China's compliance with international human rights standards, with special emphasis on the establishment of the rule of law, freedom of association and trade union freedom, women's rights, minorities' rights, freedom of religion, freedom of expression and efforts to abolish the death penalty".

31. This is particularly the case in the German programme. Interview with German Justice Ministry, June 30th 2003.

32. An example is the International Centre for Criminal Law Reform and Criminal Justice Policy (ICCLR) attached to the University of British Columbia. ICCLR has frequently taken credit for achievements of its partners, research centres at the China University of Politics and Law, when its contribution was one among many, and has also tended to exaggerate the implications of reforms, such as the revisions of the Criminal Procedure Law. See annual reports available at: http://www.icclr.law.ubc.ca/. 33. See European Commission, "Annual Report 2001 on the EC Development Policy and the Implementation of External Assistance", financial tables pp. 191-5; and EC, "Report on the Implementation of the European Commission's External Assistance, Situation at 01/01/01", financial tables on pp. 156-60.

34. Michael W. Dowdle, "Heretical Laments: China and the Fallacies of 'Rule of Law"' Cultural Dynamics, Vol. 11, No. 2, p. 308.

35. See Randall Peerenboom, China's Long March Toward Rule of Law, Cambridge, Cambridge University Press, 2002, pp. 65-7, for a definition.

36. Brian Z. Tamanaha, “The Rule of Law for Everyone?" paper for Conference on Comparative Conceptions of the Rule of Law in Asia, the University of Hong Kong, June 2002, p. 6.

37. Peerenboom, China's Long March Toward Rule of Law, p. 6. The latter part of this phrase is often omitted in English renderings.

38. Kanishka Jayasuriya, "Introduction", in Jayasuriya, ed., Law, Capitalism and Power in Asia, Routledge, 1999, pp. 2-3.

39. Jacques DeLisle, "Chasing the God of Wealth while Evading the Goddess of Democracy: Development, Democracy and Law in Reform-Era China", in Sunder Ramaswamy and Jeffrey Casson, eds, Development and Democracy: New Perspectives on an Old Debate, University Press of New England, 2003; and Carol Jones, "Politics Postponed: Law as a substitute for politics in Hong Kong and China", in Jayasuriya, op. cit., 1999.

40. International Council, Local Perspectives, p. 89.

41. Carothers, "Promoting the Rule of Law Abroad"; and Jess T. Ford, "Former Soviet Union: U.S. Rule of Law Assistance has had Limited Impact and Sustainability", Testimony to Congress from the United States General Accounting Office, May 17th 2001.

42. Erik G. Jensen, "The Rule of Law and Judicial Reform: The Political Economy of Diverse Institutional Patterns and Reformers' Responses", in Jensen and Thomas Heller, 
eds, Beyond Common Knowledge: Empirical Approaches to the Rule of Law, Stanford University Press, Stanford California, 2003, p. 344.

43. Carothers, "Promoting the Rule of Law Abroad", p. 10, and "Project Report on the Role of Foreign Aid for Legal Reform Programs in the Russian Federation", Woodrow Wilson School of Public and International Affairs, Graduate Policy Workshop on Legal Reform Projects After Communism, January 1999, pp. 73-4.

44. Thomas C. Heller, "An Immodest Postscript", in Jensen and Heller, Beyond Common Knowledge, p. 404-5.

45. Hualing Fu, "Putting China's Judiciary into Perspective: Is it Independent, Competent and Fair?" in Jensen and Heller, Beyond Common Knowledge, pp. 193-219. 46. COWI, "Democratisation-Access to Justice, Constitutional and Legislative Processes" (draft final report), commissioned by Danida, August 1999, p. 49 states: "[S]trengthening the formal legal system is more likely to help rich/commercial groups than the poor or the rural people. Their access to justice will normally to a large extent be catered to through informal/traditional systems of dispute settlements, which tend to become neglected when the formal system is strengthened".

47. I am indebted for this point to Tai Xuesen.

48. See for example Hualing $\mathrm{Fu}$, "Shifting Landscape of Dispute Resolution in Rural China" in Chen Jianfu et al., eds, Implementation of Law in the People's Republic of China, The Hague, Kluwer Law International, 2002.

49. I am indebted to Ben Liebman for this point. This has occurred to a certain extent in Cambodia and Mozambique, see COWI, "Democratisation", p. 49.

50. Kevin O'Brien describes what he calls "rightful resistance" by rural protesters against injustice, in which extensive use is made of citations from laws, regulations and official policies. O'Brien "Rightful Resistance”, World Politics, Vol. 49, No. 1, 1996, p. 31-55. But as Clarke points out, O'Brien does not even mention courts. "Nor is this failure to mention courts an oversight or a mistake. It is simply an accurate reflection of their usefulness in the eyes of rural protesters". Donald C. Clarke, "Empirical Research in Chinese Law", in Jensen and Heller, Beyond Common Knowledge, p. 183. 51. Carnegie Endowment for International Peace Roundtable, "Making Law Reform Work", Friday, November 16th 2001, at www.ceip.org.

52. International Council, Local Perspectives, pp. 89-90.

53. Examples are Supreme People's Procuratorate, "Opinions Concerning the Implementation of the Three Year Reform of Procuratorial Work", January 10th 2000; and Supreme People's Court, "Five Year Reform Programme for the People's Courts" (Renmin fayuan wunian gaige gangyao), October 20th 1999, published in book of the same name, edited by the Supreme People's Court Research Office, People's Courts Publishing House (Peking), 2000.

54. For example, the Danish agency Danida insisted that the Ugandan judiciary work out a reform plan as a condition for giving aid to support its implementation, and provided support for the planning process. Danida, Evaluation.

55. Rosemary Foot, Rights Beyond Borders: The Global Community and the Struggle over Human Rights in China, Oxford University Press, 2000, p. 239.

56. In the ten years since the Vienna World Conference, guidelines for drafting such plans have been worked out. The drafting process is envisaged as part of a national consultation on priorities and problems, involving all interested social actors. See office of the High Commissioner for Human Rights, Handbook on National Human Rights 
Plans of Action, Professional Training Series No. 10, Geneva, United Nations, 2002, available at: http://www.unhchr.ch/html/menu6/2/training.htm.

57. Li Yuwen, "Court Reform in China: Problems, Progress and Prospects", in Chen and. al., Implementation of Law in the PRC, p. 81.

58. Peerenboom, China's Long March, p. 10.

59. Chen Jianfu, "Implementation of Law as a Politico-Legal Battle in China", China Perspectives, No. 43, September-October 2002, p.27.

60. Li, "Court Reform in China", p. 80.

61. These were linked to human rights concerns as they were built on contacts initiated during and after a 1991 mission to look into the human rights situation in China headed by former Foreign Secretary Lord Geoffrey Howe.

62. Anders Mellbourn and Marina Svensson, "Swedish Human Rights Training in China: An Assessment", SIDA Studies in Democracy and Human Rights, February 1999, p. 14.

63. Fleay, "The Australia-China HRTC", citing interview with HREOC official.

64. RWI, "Plan of Operations, 2002-03".

65. Paul Knox, "Human Rights Cut in Canada's China plan", Globe and Mail, December 17th 2002. The justification offered by CIDA officials for the change was that the term human rights did not appear in the Chinese version of the paper and the two versions should be harmonised.

66. Paul Knox, " Government does quick a about-face after controversy over its decision to cut human rights from aid strategy, " Globe and Mail, December 18th 2002. But as of November 2003, the paper has still not been released, and there was no indication of whether the offending terms would appear in the Chinese version.

67. RWI, "Plan of Operations, 2002-03".

68. Sophia Woodman, "Words Obscure Actions: Human Rights Research in China", GSC Quarterly, Fall 2002, at: http://www.ssrc.org/programs/gsc/gsc_quarterly/ newsletter6/.

69. Zhang Gang, "Free money? Foreign non-profit funds seek to influence China through grant aid" (Bai gei de qian: feiyinglixing waiguo jijin tongguo wuchang yuanzhu yingxiang Zhongguo), News Weekly (Xinwen zhoukan), June 10th 2002, p. 25, quoting Li Yong, director of the Ministry of Civil Affairs Department of Registration and Management of Social Organizations with a Foreign Element.

70. Cited in RWI, "Plan of Operations, 2002-03".

71. RWI, "Human Rights Capacity Building Programme Annual Report 2001", p. 14.

72. Interview, RWI, March 1st 2003.

73. Communication from RWI, July 23rd 2003.

74. Communication from NCHR, July 17th 2003.

75. A comprehensive list of legal projects by different donors is available in Asian Development Bank, Office of the General Council, Law and Policy Reform Bulletin, 2001 edition. Some of the major projects in economic law are also described briefly in Clarke, "Empirical Research in Chinese Law", pp. 164-5.

76. "Limited evidence" from the OECD Development Assistance Committee (DAC) pointed to approximately $8 \%$ of aid worldwide being spent on human rights, democratisation and good governance in 1995 , but $85 \%$ of this went to economicoriented projects and government administration, with "human rights monitoring and education" absorbing less than 1\%. Figures cited in A Call to End Global Poverty: Renewing Canadian Aid Policy and Practice, Canadian Council for International Cooperation, March 1999, p. 36. 
77. "Annex, Terms of Reference", in Synthesis Report on EC Activities in the Field of Human Rights, Democracy and Good Governance, European Commission, August 2001, p. 6.

78. Interview with CIDA, April 16th 2003, Interview with NCHR, February 5th 2003.

79. Sorbo and Tostensen, "Aid for Human Rights and Democracy", p. 218. For example, they cite a SIDA study on evaluating HRD programmes which found that since they covered such a wide range of activities, developing standard processes for evaluation would be "unrealistic".

80. International Council, Local Perspectives, p. 87.

81. Ann Kent ("States Monitoring States: The United States, Australia, and China's Human Rights, 1990-2001”, Human Rights Quarterly, No. 23, 2001, p. 618) states that the Australian aid projects were "worthwhile achievements" based only on information from government about what was done; and the UK House of Commons, Foreign Affairs Committee, $10^{\text {th }}$ Report, cited above, lists a number of UK-funded projects and assumes that any co-operation in this field represents "success".

82. International Council, Local Perspectives, p. 88.

83. A rare exception is the UK Human Rights Project Fund, which in its early years provided several grants to the Hong Kong office of the organisation Human Rights in China.

84. See "China-Australia Human Rights Technical Cooperation Programme: Background Information", p. 4; and "Activities being implemented under the current ROU (2002/03)", document supplied by AusAID.

85. Australia's own recent record of commitment to the treaty reporting process is questionable, at best. See for example, Australian Lawyers for Human Rights, "Condemnation of Australia's human rights stance", ALHR Newsletter, Vol. 4.3, October 2000. Available at: http://www.alhr.asn.au/documents/alhrnews0010.doc.

86. Interview with project implementer, October 2nd 2002.

87. Chapter Three, Liangda Sifa Jiguan Geju Wenti (The Issue of the Inter-relationships Between the Two Principal Judicial Organs), in Liu Lixian and Zhang Zhihui, eds, Sifa Gaige Redian Wenti (Hot Topics Relating to the Judicial Reform), The Chinese People's Public Security University Publishing House (July 2000), p. 58, cited in Song Bing, A Review of Selected Judicial Reform-Related Projects Funded by the Ford Foundation, unpublished paper on file with the author. The Liu and Zhang book implied that the Ford Foundation was advancing a particular agenda in its support for the courts.

88. RWI launched such a project in 1999 and CIDA and Danish Institute for Human Rights (DIHR) also have projects in development.

89. William P. Alford, "A Second Great Wall? China's Post-Cultural Revolution Project of Legal Construction", Cultural Dynamics, Vol. 11, No. 2, 1999, p.204.

90. Interviews with project implementers.

91. This project had a budget of $€ 13.5$ million. See http://www.legaljudicial.org/ for details.

92. Chinese scholar interview.

93. Carothers, "Promoting the Rule of Law Abroad", p. 14.

94. Chinese scholar interview; comments from Titi Liu and Yash Ghai; "Project Report ...Russian Federation", p. 80.

95. Clarke, "Empirical Research in Chinese Law".

96. According to one person familiar with the project planning process, Chinese partners get tired of repeatedly answering the same questions asked by Canadians, as 
for each new project, the people involved want to learn from scratch, apparently without relying on experts to inform them.

97. Jensen, "The Rule of Law and Judicial Reform", p. 366.

98. Fleay, "The Australia-China HRTC".

99. An example in Peerenboom, "The Ford Foundation and Legal Reform in China", is that there have been a number of projects supporting production of manuals for judges, but no follow up to see if they are being used.

100. Jensen, "The Rule of Law and Judicial Reform", pp. 361-5.

101. To give just a few examples, from 1996-1999, the Canadian ICCLR received over a third of its budget for its China programme, see ICCLR annual reports 1996-7, 1997-8, 1998-9, available at: http://www.icclr.law.ubc.ca/Site\%20Map/Publications\%20Page/ Annual_Reports.htm; for the Australian HREOC, China projects were not only an infusion of funds, but also a way of proving its usefulness to a government that had imposed a $42 \%$ overall budget cut on the agency, see Oxfam Community Aid Abroad, "Australian Federal Election Report: Human Rights", on 2001 election, at http:// www.caa.org.au/current/election/humanrights.html; and both the Norwegian Centre for Human Rights and the Danish Institute for Human Rights are almost entirely dependent on their respective foreign ministries for funding.

102. Individuals involved in the programmes of Australia, Canada, the UK and the EU were mostly generous with their time in providing such information as they were allowed to give. EU projects with information on-line include the EU-China Legal and Judicial Cooperation Project: http://www.legaljudicial.org, and the EU-China Human Rights Network: http://www.eu-china-humanrights.org.

103. German Technical Cooperation Corporation. See their Web site: http://www.gtzlegal-reform.org.cn/

104. This term is now a common feature of donor parlance, indicating a recognition that previous ways of working in which donors chose what to do and how to do were generally unsuccessful.

105. Interview RWI, October 2nd 2003, communication from The Rights Practice, June 10 th 2003.

106. Some donors, such as Canada, actually require that Canadian individuals and/or groups are involved in any project funded by CIDA. At the other end of the spectrum, the Netherlands grant-giving programme for rule of law projects in China can provide funding for Chinese organisations or joint projects between them and groups outside China (not limited to those from the Netherlands).

107. The limited literature in China on aid shows a realist view of the motives for aid, with the assumption being that donor interests are the most important factor in shaping topics and styles of co-operation. See, for example, "Summary report on conference to announce results of research project 'Foreign Aid and International Relations'" ("duiwai yuanzhu yu guoji guanxi" chengguo fabuhui ji yantaohui zongshu), Europe (Ouzhou), No. 2, 2002, as well as cited article from News Weekly.

108. Interview, RWI, March 1st 2003.

109. Communication from The Rights Practice, June 6th 2003.

110. Communication from The Rights Practice, June 10th 2003.

111. Interview EC, December 3rd 2003.

112. While the lag between project approval and funds disbursement is a common feature of the EC aid system, in many cases projects in China have taken three or more years to get off the ground. 
113. Implementing agencies seem more likely to do this on a systematic basis.

114. See RWI, "Plan of Operations for the Human Rights Capacity Building Programme in China 2002-03", April 2002.

115. Interview, RWI, March 1st 2003.

116. Apart from postponements of some RWI courses in the early years of the cooperation, the only reasons for projected projects not eventually coming to fruition were excessive demands for funds from some Chinese partners.

117. Conversation with John Ohnesorge, University of Wisconsin.

118. See for example, David Zweig, "The Open Door and Foreign Donors: Can China Keep Control?" paper presented at the 2000 annual meeting of the Association for Asian Studies.

119. Javier Ciurlizza, "Judicial Reform and International Legal Technical Assistance in Latin America", Democratization, Vol. 7, No. 2, Summer 2000, p. 226, emphasis added.

120. Interview, British Council, June 16th 2003.

121. "Project Report... Russian Federation", p. 23

122. For example, proposals for funding from the organisation Human Rights in China to AusAID's Human Rights Small Grants Scheme in 2000 and 2001 were turned down despite having the support of officers in the Hong Kong consulate and the Peking embassy. The group was told the projects in question, which related to the treaty monitoring process and the right to education, were not seen by officials in Canberra as having any impact in China.

123. Chinese scholar interview. However, one person involved in project implementation pointed out that scholars might be more critical of the current focus of donors' work, since the shift to more work on law implementation had meant that academics had lost out. Interview, June 20th 2003.

124. As Peerenboom writes, "Although legal reforms are often described as top-down, in fact many initiatives for reform come from those working on the front lines". "The Ford Foundation and Legal Reform in China", 2001.

125. Interview ICCLR May 12th 2003.

126. Various conversations with diplomats and interviews with staff of implementing agencies.

127. In particular, see annual reports of RWI and NCHR.

128. See for example, Linn Hammergren, "Judicial Training and Justice Reform", Center for Democracy and Governance, USAID, August 1998.

129. Communication from RWI, July 23rd 2003.

130. China Economic Quarterly, "The China Market: Migration cuts the income gap between cities and farms", South China Morning Post, February 24th 2003.

131. DVN receives funding from some of the donors covered in this study, but to my knowledge, the work of Wan Yanhai and other HIV/AIDS activists receives support only from private foundations.

132. See annual reports from ICCLR, available at: http://www.icclr.law.ubc.ca/

133. In particular projects implemented by the Great Britain-China Centre and The Rights Practice in Shanghai.

134. Implemented by Save the Children Fund UK.

135. Linn Hammergren, "Political Will, Constituency Building and Public Support in Rule of Law Programs", Centre for Democracy and Governance, USAID, August 1998. 
INDEX

Thèmes : relations internationales 